Ariska, et al/Jurnal Ekonomi Syariah Teori dan Terapan Vol. 6 No. 12 Desember 2019: 2471-2484; PENYELESAIAN PEMBIAYAAN BERMASALAH AKAD MURABAHAH PADA BANK PEMBIAYAAN RAKYAT SYARIAH PATRIOT BEKASI

\title{
PENYELESAIAN PEMBIAYAAN BERMASALAH AKAD MURABAHAH PADA BANK PEMBIAYAAN RAKYAT SYARIAH PATRIOT BEKASI 1
}

\author{
Merlin Dewi Ariska \\ Departemen Ekonomi Syariah-Fakultas Ekonomi dan Bisnis-Universitas Airlangga \\ Email: Merlin.dewi.ariska-2015@feb.unair.ac.id \\ Dina Fitrisia Septiarini \\ Departemen Ekonomi Syariah-Fakultas Ekonomi dan Bisnis-Universitas Airlangga \\ Email: dina.fitrisia@feb.unair.ac.id
}

\begin{abstract}
:
This study aims to find out dispute settlement mechanism of the financing problem of murabahah contracts at Islamic Rural Bank or BPRS Patriot Bekasi. The research is conducted in a descriptive qualitative approach with the case study method. Informants determined using snowball sampling, and, data collection techniques using interviews, documentation, and observation. The results are analyzed by reducing data, presenting data, and making conclusions. The results of this study indicate that the financing problem of murabahah contracts at Islamic Rural Bank or BPRS Patriot Bekasi is solved carried out by implementing strategies that are conducting accurate analysis, intensive monitoring, and employee training. Meanwhile, the procedure was carried out, and even the financing problem still exists, it will be handled it will handle with preventive action (rescheduling), claims on insurance, curative actions by executing guarantees, management assistance, billing by third parties. But this method has never done by the Islamic Rural Bank Patriot Bekasi and write off, as well as the final write off.
\end{abstract}

Keywords: Financing problem, rescheduling, executing guarantees, write off

\section{PENDAHULUAN}

Kegiatan lembaga kevangan, termasuk di Indonesia tidak terpisahkan dengan kegiatan perekonomian. Salah satu lembaga kevangan syariah yang banyak diminati adalah BPRS (Bank Pembiayaan Rakyat Syariah). Pengertian BPRS menurut Undang-undang Nomor 21 Tahun 2008 adalah bank yang dalam kegiatan usahanya berlandaskan prinsipprinsip syariah dan tidak menyediakan jasa dalam lalu lintas pembayaran. Menurut statistik perbankaan Otoritas Jasa Keuangan (2019) dari beberapa akad yang digunakan BPRS dalam memberikan pembiayaan, akad murabahah memiliki jumlah yang paling besar. Hal ini menunjukan bahwa nasabah BPRS paling banyak menggunakan akad pembiayaan murabahah untuk pembiayaan. Dapat difahami bahwa dengan demikian potensi terjadinya kredit macet yang berasal dari pembiayaan dengan akad murabahah juga cukup besar.

Pembiayaan oleh BPRS tidak terlepas dari masalah, baik masalah internal maupun eksternal. Masalah yang sering muncul dan menjadi salah satu risiko BPRS adalah gagal bayar oleh nasabah. Risiko seperti ini disebut dengan pembiayaan bermasalah. Pembiayaan bermasalah biasanya terjadi jika nasabah

\footnotetext{
${ }^{1}$ Jurnal ini merupakan bagian dari skripsi dari Merlin Dewi Ariska, NIM: 041511433090, yang diuji pada 29 November 2019.
} 
Ariska, et al/Jurnal Ekonomi Syariah Teori dan Terapan Vol. 6 No. 12 Desember 2019: 2471-2484; PENYELESAIAN PEMBIAYAAN BERMASALAH AKAD MURABAHAH PADA BANK PEMBIAYAAN RAKYAT SYARIAH PATRIOT BEKASI

lalai atau terlambat dalam membayar angsuran yang disepakati diawal untuk dibayarkan tiap bulannya (Siamat, 2001:174).

Undang-undang perbankan syariah pasal 2 telah mengatur tentang pedoman yang harus digunakan oleh perbankan syariah dalam menjalankan usahanya. Pedoman tersebut adalah perbankan syariah dalam melakukan usaha harus berdasarkan prinsip syariah, demokrasi ekonomi dan prinsip kehatihatian.

Otoritas Jasa Keuangan (2019) mencatat dalam kurun waktu 2013 sampai 2017 NPF pada BPRS mengalami kenaikan tiap tahunnya. Pada tahun 2013 NPF (Non Performing Financing) BPRS sebesar 6,5\% hingga pada Desember 2017 meningkat menjadi $9,68 \%$. Besar NPF ini sudah melampaui batas maksimal NPF yang ditetapkan oleh Bank Indonesia yaitu 5\%. Mengingat hal ini BPRS harus berupaya untuk meminimumkan NPF. Hal tersebut dapat dilakukan dengan upaya meningkatkan kualitas pembiayaan atau pengawasan yang rutin pada nasabah pembiayaan dll. Pada tahun 2017 dari total pembiayaan 7.763.951, sebanyak 7.012.068 kategori lancar, sebesar 751.883 kategori non lancar. Sebesar 158.628 kategori kurang lancar, 123.194 kategori diragukan dan 470.061 kategori macet. (www.ojk.go.id)

BPRS Patriot Bekasi merupakan BUMD (Badan Usaha Milik Daerah) yang dimiliki oleh Pemerintah Kota Bekasi dan berdiri sejak tahun 2005. Menurut Radar Bekasi 23 Oktober 2018 ketika memberitakan Infobank Sharia Awards 2018, BPRS Patriot mendapat penghargaan BPRS terbaik nomor satu seIndonesia kategori BPRS dengan aset 100 Milyar sampai 250 milyar dengan predikat kinerja keuangan sangat bagus. Penghargaan ini telah pula pernah diraih oleh BPRS Patriot, yaitu pada tahun 2017 juga mendapat penghargaan dengan kategori yang sama, tetapi hanya terbaik kedua. Indikator peroleh/an penghargaan dapat diraih atas tingkat kesehatan bank yang ada di OJK Menurut data OJK (2019), hingga April 2018 NPF BPRS menyentuh angka lebih dari $10 \%$. Hal ini berarti kebanyakan NPF BPRS berada dalam kondisi tidak baik. Berbeda dengan BPRS Patriot Bekasi, NPF BPRS Patriot Bekasi masih jauh dari batas NPF yang ditetapkan oleh Bank Indonesia. Menurut Direktur Utama BPRS Patriot Bekasi yang dikutip dari republika.co.id tanggal 24 September 2018, NPF gross yang dimiliki BPRS Patriot Bekasi pada tahu 2018 sebesar 2,3\% dan NPF net sebesar 0,3\% dengan total pembiayaan per Agustus 2018 adalah sebesar 143 milyar. Kondisi ini sangat berbeda jauh dengan kondisi BPRS Patriot Bekasi pada tahun 2012 dimana NPF mencapai $70 \%$ yang jauh melebihi ambang batas yang telah ditetapkan yaitu sebesar $5 \%$.

\section{LANDASAN TEORI}

BPRS menurut Undang-Undang Nomor 21 Tahun 2008 adalah bank yang 
Ariska, et al/Jurnal Ekonomi Syariah Teori dan Terapan Vol. 6 No. 12 Desember 2019: 2471-2484; PENYELESAIAN PEMBIAYAAN BERMASALAH AKAD MURABAHAH PADA BANK PEMBIAYAAN RAKYAT SYARIAH PATRIOT BEKASI

dalam kegiatan usahanya berlandaskan prinsip syariah dan tidak menyediakan jasa dalam lalu lintas pembayaran. Bentuk hukumnya dapat berupa Perseroan Terbatas (PT), Perusahaan Daerah maupun koperasi (Pasal 2 PBI Nomor 06/17/PBI/2004). BPRS diizinkan melakukan aktivitasnya dengan modal awal saat mendirikan bank adalah sebesar tidak kurang dari 50 juta rupiah.

Menurut Peraturan Otoritas Jasa Keuangan Nomor 20/POJK.03/2018 terdapat enam risiko yang harus dihadapi oleh BPRS, diantaranya yaitu risiko kredit, risiko operasional, risiko kepatuhan, risiko likuditas, risiko reputasi dan risiko strategik. Akan tetapi yang dibahas dalam penelitian ini adalah risiko kredit. Risiko kredit berkaitan dengan kegagalan nasabah atau pihak lain dalam memenuhi kewajibannya kepada BPRS, termasuk kerugian yang ditanggung oleh BPRS karena kegagalan usaha nasabah yang dibiayai baik berbasis bagi hasil dengan metode net revenue sharing maupun metode profit and loss sharing.

Undang-Undang Nomor 10 Tahun

1998 Pasal 1 Ayat 11 mendefinisikan pembiayaan sebagai penyediaan vang atau tagihan atau yang disamakan dengan itu, berdasarkan persetujuan kreditur dan debitur atau bank dengan pihak lain yang mewajibkan debitur untuk membayar tagihan tersebut pada jangka waktu yang ditetapkan disertai dengan bunga.
Berdasarkan jenis akadnya, pembiayaan digolongkan menjadi empat, yakni pembiayaan berbasis bagi hasil yaitu dengan akad mudharabah dan musyarakah, pembiayaan berbasis jual beli yaitu murabahah, istishna, dan salam, pembiayaan berbasis sewa yaitu ijarah dan IMBT (ljarah Muntahiya Bit Tamlik) dan pembiayaan dengan akad pelengkap yaitu hiwalah, rahn, qard, wakalah, dan kafalah.

Untuk mengurangi risiko kredit atau risiko akan kegagalan nasabah dalam mengembalikan dana yang telah dipinjam maka pihak bank harus menetapkan strategi pencegahan dan penyelesaian pembiayaan bermasalah. Fatwa MUI (Majelis Ulama Indonesia) No: 47/DSN-MUI/II/2005 tentang Penyelesaian Piutang Murabahah Bagi Nasabah Tidak Mampu Bayar dapat dilakukan dengan dua cara yaitu :

1. Pemberian Keringanan

2. Penjualan Objek Transaksi

3. Rescheduling

Rescheduling adalah pembayaran kewajiban nasabah, bisa memperpanjang ataupun memperpendek jangka waktu pembayaran.

4. Restructuring

Restructuring adalah konversi akad pembiayaan dengan akad mudharabah, musyarakah, dan IMBT.

$$
\text { Menurut Karim }
$$

murabahah adalah suatu akad jual-beli di dalam akad ini, harga jual suatu barang 
Ariska, et al/Jurnal Ekonomi Syariah Teori dan Terapan Vol. 6 No. 12 Desember 2019: 2471-2484; PENYELESAIAN PEMBIAYAAN BERMASALAH AKAD MURABAHAH PADA BANK PEMBIAYAAN RAKYAT SYARIAH PATRIOT BEKASI

adalah harga beli dari barang yang ditransaksikan ditambah dengan margin yang telah disepakati antara penjual dan pembeli. Menurut Asmi (2007) dalam jurnalnya terdapat tiga risiko yang terdapat dalam akad murabahah, yaitu:

1. risiko yang terkait dengan barang

Pada skema akad murabahah, pihak bank akan membeli barang yang sesuai dengan keinginan nasabah, sehingga secara otomatis bank menanggung risiko kehilangan ataupun kerusakan barang dari pembelian hingga diserahka pada nasabah. Menurut fiqh bank berhak untuk menolak apabila barang tidak sesuai dengan spesifikasi diawal.

2. risiko yang terkait dengan nasabah

Risiko ini berkaitan dengan hak nasabah untuk menolak barang yang telah dibeli oleh bank, sehingga meskipun barang yang dibeli sesuai dengan spesifikasi nasabah memiliki hak untuk menolaknya.

3. risiko yang terkait dengan pembayaran Risiko ini berkaitan dengan terjadinya gagal bayar oleh nasabah, baik karena nasabah bangkrut ataupun kesengajaan nasabah untuk tidak membayar angsurannya kepada pihak bank.

III. METODE PENELITIAN

Pendekatan yang peneliti gunakan pada penelitian ini adalah pendekatan kualitatif deskriptif dengan metode studi kasus karena diperlukan gambaran yang jelas dalam memahami penyelesaian pembiyaan bermasalah akad murabahah pada BPRS Patriot Bekasi, sehingga dianggap pendekatan kualitatif deskriptif adalah pendekatan yang paling tepat untuk digunakan pada penelitian ini. Teknik pengumpulan data dilakukan melalui wawancara dengan empat informan, observasi di lapangan dan dokumentasi. Teknik keabsahan data penelitian ini menggunakan triangulasi sumber data yang dilakukan dengan menggali kebenaran informasi melalui berbagai metode dan sumber perolehan data. Teknik analisis data dilakukan dengan tiga tahap yaitu reduksi data, penyajian data dan penarikan kesimpulan atau verifikasi data.

\section{HASIL DAN PEMBAHASAN}

BPRS Patrioł Bekasi adalah salah satu BPRS yang terdapat di Kota Bekasi, Jawa Barat dengan modal awal yang bersumber dari dana APBD (Anggaran Pendapatan dan Belanja Daerah) sebesar Rp 2.000.000.000. BPRS Patriot Bekasi adalah BPRS pertama yang dimiliki oleh Pemerintah Kota Bekasi, sekaligus BPRS pertama yang didirikan oleh Pemerintah Daerah di Propinsi Jawa Barat.

Menurut data hasil wawancara dengan empat informan tardapat beberapa hal yang menyebabkan pembiayaan bermasalah, yang telah disajikan pada tabel dibawah ini yaitu:

Tabel 1.

Penyajian Data Penelitian Penyebab Pembiayaan Bermasalah

\section{Informan Pernyataan}

Informan "Penyebabnya yang paling 
Ariska, et al/Jurnal Ekonomi Syariah Teori dan Terapan Vol. 6 No. 12 Desember 2019: 2471-2484; PENYELESAIAN PEMBIAYAAN BERMASALAH AKAD MURABAHAH PADA BANK PEMBIAYAAN RAKYAT SYARIAH PATRIOT BEKASI

\begin{tabular}{|c|c|}
\hline Informan & Pernyataan \\
\hline $\begin{array}{c}\text { Informan } \\
2\end{array}$ & $\begin{array}{l}\text { banyak mah kayaknya sama } \\
\text { kayak di bank bank yang lain } \\
\text { mbak, ya karakter nasabah } \\
\text { itu paling banyak sama } \\
\text { usahanya nasabah biasanya } \\
\text { lagi turun gitu jadi ngefek } \\
\text { sama pendapatannya dia." } \\
\text { "Jadi ada faktor internal ada } \\
\text { faktor eksternal neng, faktor } \\
\text { eksternal ini yang kita gabisa } \\
\text { ngontrol, ya mau gak mau ya } \\
\text { kudu di hadapi" } \\
\text { "Ya.. seperti inflasi, nilai kurs, } \\
\text { GDP yang makro makro itu } \\
\text { lah neng" } \\
\text { "Faktor internal ini bisa dari } \\
\text { bank sama dari nasabahnya } \\
\text { neng, dari bank ya biasanya } \\
\text { kesalahan manajerial, kalo } \\
\text { dari nasabah ini bisa jadi } \\
\text { karena keuntungannya lagi } \\
\text { turun atau bahkan yang } \\
\text { paling banyak itu karakter } \\
\text { nasabah neng" }\end{array}$ \\
\hline $\begin{array}{c}\text { Informan } \\
3\end{array}$ & $\begin{array}{l}\text { "Penyebabnya ini dari internal } \\
\text { bank sendiri sama faktor } \\
\text { nasabah" } \\
\text { "Kalo dari internalnya bank ini } \\
\text { biasanya karena waktu ada } \\
\text { pengajuan pembiayaan } \\
\text { masuk ini kurang akurat } \\
\text { analisisnya kan masuk } \\
\text { biasanya ke AO ya mbak" } \\
\text { "Apa lagi ya mbak... emm } \\
\text { inii..Sama lemahnya } \\
\text { monitoring dan pengawasan" } \\
\text { "Kalau yang berasal dari } \\
\text { nasabah ini biasanya } \\
\text { usahanya lagi gak laku, jadi } \\
\text { pendapatannya turun, sama } \\
\text { yang paling sering ya } \\
\text { nasabah berkarakter mbak, } \\
\text { ini paling banyak oh iya ada } \\
\text { lagi kalo nasabahnya } \\
\text { meninggal" }\end{array}$ \\
\hline $\begin{array}{c}\text { Informan } \\
4\end{array}$ & $\begin{array}{l}\text { "Ya yang pertama dan } \\
\text { utama tuh karena attitude } \\
\text { nasabah mbak, ya biasa } \\
\text { nasaba nasabah nakal teruss } \\
\text { ada juga karena nasabah } \\
\text { pendapatannya turun, gara } \\
\text { gara di PHK misalnya, teruss } \\
\text { usaha nasabah lagi gak }\end{array}$ \\
\hline
\end{tabular}

\begin{tabular}{cc}
\hline Informan & Pernyataan \\
\hline \multicolumn{3}{c}{$\begin{array}{l}\text { lancar, samaa ada juga } \\
\text { nasabahnya meninggal } \\
\text { dunia" }\end{array}$} \\
\hline Sumber : Data diolah peneliti \\
Berdasarkan informasi dari
\end{tabular}

keempat informan tersebut, dapat ditarik kesimpulan hal-hal yang dapat menyebabkan pembiayaan bermasalah adalah:

1. Karakter nasabah

2. Penurunan pendapatan nasabah yang disebabkan penurunan usaha

3. Faktor eksternal (GDP, inflasi, nilai kurs)

4. Kesalahan manajerial

5. Analisis pembiayaan yang kurang akurat

6. Monitoring dan pengawasan yang lemah

7. Nasabah meninggal dunia

8. Penurunan pendapatan nasabah yang disebabkan pemutusan kerja

Upaya pencegahan dalam pembiayaan bermasalah harus ditangani sedini mungkin untuk menghindari semakin memburuknya pembiayaan. Sehingga perlu strategi-strategi khusus dalam pencegahan pembiayaan bermasalah. Hal ini dijelakan oleh informan di bawah ini.

Tabel 2.

Penyajian Data Penelitian Strategi Pencegahan Pembiayaan Bermasalah

\begin{tabular}{ll}
\hline Informan & \multicolumn{1}{c}{ Pernyataan } \\
\hline Informan & "Jadi gini pembiayaan \\
$\mathbf{2}$ & bermasalah itu kuncinya \\
& diawal, kalo analisisnya \\
& bagus, monitoring dan \\
& pengawasannya bagus, \\
& sebenarnya pembiayaan \\
& bermasalah itu kecil, yaaa \\
\hline
\end{tabular}


Ariska, et al/Jurnal Ekonomi Syariah Teori dan Terapan Vol. 6 No. 12 Desember 2019: 2471-2484; PENYELESAIAN PEMBIAYAAN BERMASALAH AKAD MURABAHAH PADA BANK PEMBIAYAAN RAKYAT SYARIAH PATRIOT BEKASI

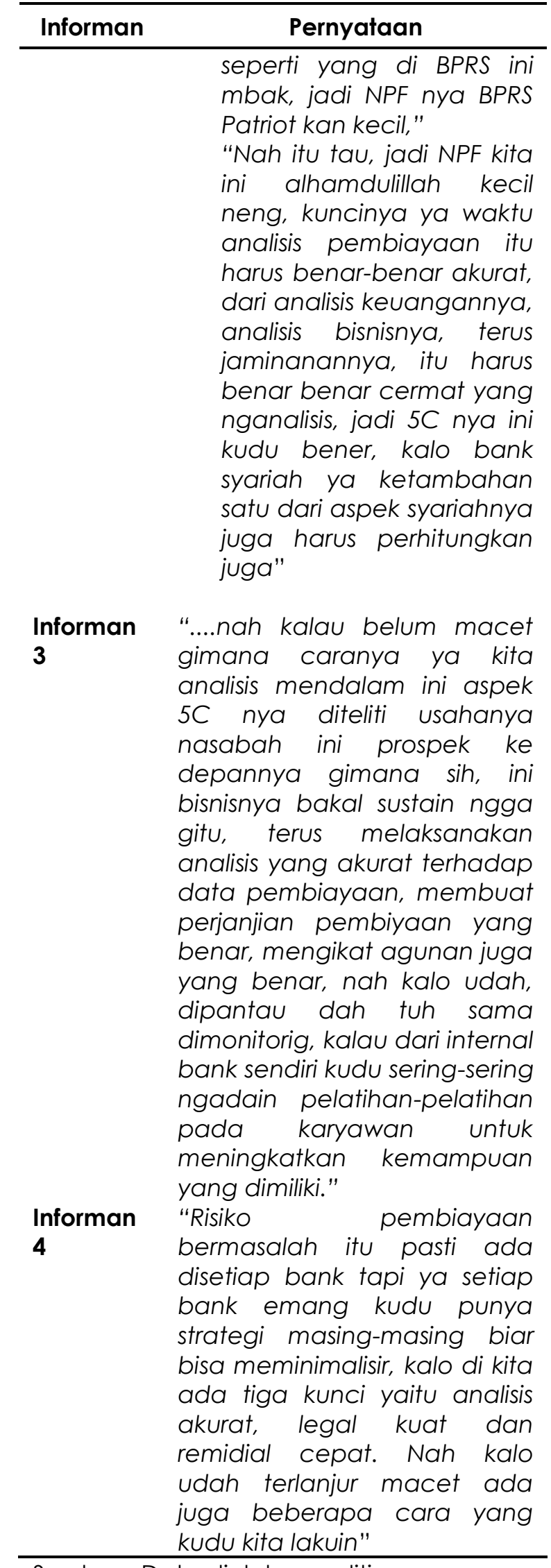

Sumber : Data diolah peneliti
Strategi-strategi untuk mencegah pembiayaan bermasalah menurut informan 2, yaitu bapak Wagiman selaku divisi remidial BPRS Patriot Bekasi adalah :

1. menganalisis pengajuan pembiayaan dengan tepat dan akurat, seperti analisis kevangan, bisnis, jaminan, dan $5 \mathrm{C}+\mathrm{S}$

2. melakukan pengawasan dan monitoring yang lebih intensif

Strategi-strategi untuk mencegah pembiayaan bermasalah menurut informan 3, yaitu bapak Fasih selaku kepala divisi bisnis BPRS Patriot Bekasi adalah:

1. melakukan analisis yang akurat (data pembiayaan, aspek 5C, aspek bisnis)

2. membuatan perjanjian pembiayaan yang benar

3. pengikatan agunan yang benar

4. pemantauan dan pengawasan (monitoring) pembiayaan yang intensif

5. pelatihan pada karyawan BPRS Patriot Bekasi

Strategi-strategi untuk mencegah pembiayaan bermasalah menurut informan 4, yaitu bapak Asmawi selaku direksi BPRS Patriot Bekasi adalah :

1. melakukan analisis pembiayaan dengan akurat

2. pengikatan jaminan yang kuat

3. melakukan remidial dengan cepat

Menurut empat informan juga terdapat beberapa cara yang digunakan untuk menyelesaikan pembiayaan bermasalah pada BPRS Patriot Bekasi 
Ariska, et al/Jurnal Ekonomi Syariah Teori dan Terapan Vol. 6 No. 12 Desember 2019: 2471-2484; PENYELESAIAN PEMBIAYAAN BERMASALAH AKAD MURABAHAH PADA BANK PEMBIAYAAN RAKYAT SYARIAH PATRIOT BEKASI

yang telah disajikan dalam tabel dibawah ini:

Tabel 3.

Penyajian Data Penelitian tentang Penyelesaian Pembiayaan Bermasalah

\begin{tabular}{|c|c|}
\hline Informan & Pernyataan \\
\hline $\begin{array}{c}\text { Informan } \\
1\end{array}$ & $\begin{array}{l}\text { "nah biasanya kalo } \\
\text { sebelumjatuh tempo nih, kita } \\
\text { AO bakal ngehubungin } \\
\text { nasabah buat ngingetin kalo } \\
\text { bentar lagi jatuh tempo, kalo } \\
\text { nasabah sampe jatuh tempo } \\
\text { masih belom bayar-bayar ya } \\
\text { kita ngirim surat penagihan } \\
\text { dulu, kalo surat penagihan } \\
\text { masih belom mempan ya kita } \\
\text { ngeluarin SP, surat peringatan } \\
\text { terusss sampe SP 3" } \\
\text { "ya kita ambil barang } \\
\text { jaminannya, beda lagi kalo } \\
\text { macetnya gara gara } \\
\text { usahanya lagi turun" } \\
\text { "ya bisa dilakukan } \\
\text { rescheduling mbak, tapi ini } \\
\text { nasabahnya kudu kooperatif } \\
\text { ya, maksutnya dia ngomong } \\
\text { terus terang nih masalahnya } \\
\text { dia apa sampe bisa telat, nah } \\
\text { ini namanya nasabah } \\
\text { kooperatif, kan biasanya ada } \\
\text { tuh nasabah yang ketika } \\
\text { dihubungin gamau jawab, } \\
\text { bilang mau bayar, janji bayar } \\
\text { eh ternyata gak bayar bayar } \\
\text { sampe bener-bener macet. } \\
\text { Kalo nasabah terus terang } \\
\text { misal karena usahanya lagi } \\
\text { turun jadi pendapatannya } \\
\text { turun, kalo gak gitu lagi pindah } \\
\text { kerja terus dapet gaji yang } \\
\text { lebih dikit ya kita bantu, bisa } \\
\text { kita lakuin rescheduling" }\end{array}$ \\
\hline $\begin{array}{c}\text { Informan } \\
2\end{array}$ & $\begin{array}{l}\text { "Kalo disebabkan hal yang } \\
\text { lain, kayak yang saya bilang } \\
\text { tadi, misalnya keuntungan } \\
\text { nasabahnya turung ya kita } \\
\text { lakuin revitalisasi akad, tau kan } \\
\text { mbak?" } \\
\text { "lya ada tiga, rescheduling, } \\
\text { reconditiong sama } \\
\text { restructuring tapi selama ini } \\
\text { BPRS Patriot cuma make }\end{array}$ \\
\hline
\end{tabular}

rescheduling setau saya neng, ntar coba tanya sama yang lain ya apa pernah make yang selain rescheduling soalnya setau saya ya cuman itu ajah" "Langsung sikat jaminannya neng"

Informan "Kalo udah by accident 3 biasanya bisa dengan rescheduling, bisa eksekusi jaminan, yah tergantung sih nasabah yang kita hadapi masalahnya gimana dulu, terus misal kalo nasabah meninggal itu biasanya kita langsung klaim ke asuransi"

Informan "Ada banyak cara mbak, bisa 4 di AYDA, bisa dengan reschedulling akad, bisa kalo meninggal itu di cover asuransi, jadi ntar kita ngeklaim, atau hiwalah bisa juga"

"Nggak langsung di AYDA juga sih mbak sebenernya jadi misal nasabah ini bermasalah gak bayar-bayar ya yang saya katakan attitude tadi mbak itu bank bakal ngasih tekanantekanan dulu sampe dia mau bayar, kita gak butu-buru ngasih SP juga mbak, soalnya kalo kita buru-buru ngasih SP ntar kudu langsung eksekusi mbak, jadi tiga tekanan ini, penekanan secara administrasi ada lagi... penekanan psikologis jadi nasabahnya ini ditelvonnn teruss dihubungii teruss sama penekanan dengan mendatangi keluarganya, nah kalo gak mempan ya kita datengin nih keluarga nasabahnya"

"Eh ada sih mbak satu, ini kayak bener bener cara terakhir dari yang paling akhir, kalo udah mentok banget yaitu di write off atau nama lainnya di hapus buku ada juga write off final jadi kalo udah final ini hapus buku ya hapus tagih."

Sumber : Data diolah peneliti 
Ariska, et al/Jurnal Ekonomi Syariah Teori dan Terapan Vol. 6 No. 12 Desember 2019: 2471-2484; PENYELESAIAN PEMBIAYAAN BERMASALAH AKAD MURABAHAH PADA BANK PEMBIAYAAN RAKYAT SYARIAH PATRIOT BEKASI

Berdasarkan informasi dari keempat informan tersebut, dapat ditarik kesimpulan hal-hal yang dapat dilakukan untuk menangani pembiayaan bermasalah adalah:

1. Mengirimkan surat penagihan, jika masih belum dibayar maka mengirimkan surat peringatan I,II dan III

2. Melakukan Rescheduling

3. Mengklaim pada asuransi

4. Melakukan eksekusi jaminana

5. Write off dan write off final

Proses nasabah saat melakukan pengajuan pembiayaan pada BPRS Patriot Bekasi harus mengisi formulir pembiayaan dan mengumpulkan persyaratan administrasi. Selanjutnya adalah account officier akan melakukan analisis dan pengecekan sebelum dilakukan pengkomitean dengan pimpinan. Jika sudah diajukan pada komite pembiayaan dan disetujui selanjutnya akan diteruskan ke bagian legal (unit support) untuk dibuatkan akad yang cocok dan pengecekan jaminan. Selanjutnya account officier akan melakukan pengikatan akad dengan nasabah dan dilanjutkan realisasi pembiayaan.

Jika suatu pembiayaan telah disetujui maka strategi pencegahan pembiayaan bermasalah sudah dimulai. Strategi pencegahanan juga memiliki peran penting untuk meminimalisir adanya pembiayaan bermasalah. Pencegahan ini dilakukan oleh BPRS Patriot Bekasi dengan menganalisis secara akurat terhadap pengajuan pembiayaan, pengawasan dan monitoring yang intensif dan berkelanjutan, serta pelatihan manajerial yang bertujuan untuk meningkatkan kemampuan karyawan.

1. Menganalisis secara akurat terhadap pengajuan pembiayaan

Proses analisis adalah proses awal yang menentukan suatu pembiayaan akan berada pada kategori pembiayaan lancar ataukah pembiayaan bermasalah. Menurut informan 2 dan 3 , SOP BPRS Patriot Bekasi dan buku standar produk murabahah dari OJK penganalisisian secara akurat penting dilakukan. Menganalisis secara akurat terhadap pengajuan pembiayaan dapat dilakukan dengan meneliti secara mendalam aspek $5 \mathrm{C}+\mathrm{S}$ atau menganalisis keuangan, bisnis, manajemen, industri, yuridis, risiko makro maupun jaminannya.

2. Pengawasan

Pada dasarnya pengawasan pembiayaan bertujuan untuk membantu petugas bagian pembiayaan melaksanakan tanggung jawabnya secara efektif dan efisiensi, dengan demikian diharapkan peluang penyimpangan dapat diminimalkan dan dideteksi sejak awal. Pengawasan pembiayaan lebih difokuskan kedalam atau pada prosedur BPRS Patriot Bekasi. Pengawasan pembiayaan harus meliputi semua aspek pembiayaan serta semua objek pengawasan tanpa pengecualian, yaitu pejabat bank 
Ariska, et al/Jurnal Ekonomi Syariah Teori dan Terapan Vol. 6 No. 12 Desember 2019: 2471-2484; PENYELESAIAN PEMBIAYAAN BERMASALAH AKAD MURABAHAH PADA BANK PEMBIAYAAN RAKYAT SYARIAH PATRIOT BEKASI

yang terkait dengan pembiayaan, semua jenis pembiayaan, file pembiayaan dan nasabah

3. Monitoring

Sebuah pembiayaan juga harus memiliki monitoring yang baik, tujuannya adalah untuk menghindari pembiayaan bermasalah. Informan 2 dan 3 menjelaskan bahwa kurangnya monitoring juga menyebabkan pembiayaan bermasalah.

4. Pelatihan Manajerial

Pelatihan managerial juga diperlukan untuk meningkatkan kemampuan karyawan, terutama yang terlibat dalam menanganin sebuah pembiayaan. Karyawan menjadi modal penting sebagai sumber daya insani yang menjadi tonggak untuk menilai kelayakan sebuah pembiayaan. Pembiayaan yang berkualitas adalah hasil dari karyawan yang berkualitas juga.

Menurut Ubaidillah (2018) dalam jurnalnya, pembiayaan bermasalah atau dalam bahasa Inggris disebut Non Performing Financing (NPF) merupakan rasio pembiayaan bermasalah terhadap total pembiayaan. NPF adalah pembiayaan yang kualitasnya berada dalam golongan dalam perhatian khusus, kurang lancar, diragukan, dan macet. Kriteria penilaian kualitas pembiayaan dari segi kemampuan bayar berdasarkan kelompok produk pembiayaannya yaitu:
1. lancar yaitu Pembayaran angsuran tepat waktu dan tidak ada tunggakan serta sesuai dengan persyaratan akad.

2. dalam perhatian khusus yaitu terdapat tunggakan pembayaran angsuran pokok dan atau margin s/d 90 hari.

3. kurang lancar yaitu terdapat tunggakan pembayaran angsuran pokok dan atau margin yang telah melewati 90 hari s/d 180 hari.

4. diragukan yaitu erdapat tunggakan pembayaran angsuran pokok dan atau margin yang telah melewati 180 hari s/d 270 hari.

5. macet yaitu terdapat tunggakan pembayaran angsuran pokok dan atau margin yang sudah melewati 270 hari.

Jika pembiayaan sudah bermasalah maka perlu upaya penyelesaian yang harus segera dilakukan. Penyelesaian pembiayaan bermasalah pada BPRS Patriot berdasarkan empat informan, SOP BPRS Patriot dan buku standar produk murabahah adalah sebagai berikut.

1. Tindakan Prefentif

Penyelesaian pembiayaan bermasalah dapat dilakukan dengan tindakan prefentif sebelum pembiayaan bermasalah semakin memburuk. Berdasarkan SOP BPRS Patriot disebutkan bahwa tindakan prefentif dilakukan dengan restructuring, reconditioning, rescheduling, akan tetapi pada poin empat disebutkan bahwa yang diperbolehkan secara syariah hanya 
Ariska, et al/Jurnal Ekonomi Syariah Teori dan Terapan Vol. 6 No. 12 Desember 2019: 2471-2484; PENYELESAIAN PEMBIAYAAN BERMASALAH AKAD MURABAHAH PADA BANK PEMBIAYAAN RAKYAT SYARIAH PATRIOT BEKASI

rescheduling. Pada buku pedoman standar murabahah juga hanya menyebutkan rescheduling. Hasil wawancara dengan informan 3 juga menyebutkan bahwa selama ini BPRS Patriot hanya pernah menggunakan cara rescheduling. Rescedulling adalah penyelesaian pembiayaan bermasalah yang dilakukan dengan merubah jadwal pembayaran kewajiban nasabah atau jangka waktu pembayarannya.

Rescheduling dilakukan dengan syarat nasabah bukan termasuk nasabah berkarakter, dimana nasabah masih kooperatif dengan bank. Ketika melakukan rescheduling bank tidak boleh meminta tambahan atas kewajiban yang dibayar oleh nasabah. Besar pembiayaan yang baru adalah sisa pokok dan margin dari pembiayaan awal. Nasabah hanya membayar biaya administrasi dan asuransi.

\section{Klaim Asuransi}

Menurut informan 3 dan 4 pembiayaan bermasalah bisa terjadi ketika nasabah meninggal. Ketika nasabah meninggal penanganan pembiayaan bermasalahnya dilakukan dengan cara mengklaim pada asuransi sebesar sisa kewajiban nasabah, dengan catatan nasabah tidak melakukan keterlambatan pembayaran. Jika nasabah melakukan keterlambatan pembayaran maka ahli waris harus membayar terlebih dahulu kewajiban yang belum dibayar, dan sisanya akan dilakukan klaim pada asuransi. Tetapi jika sampai akhir jatuh tempo pembayaran nasabah meninggal dan belum melunasi kewajibannya maka dilakukan akad hiwalah yaitu pengalihan hutang nasabah pada ahli warisnya, sehingga ahli waris harus melunasi hutang nasabah.

3. Tindakan Kuratif

Tindakan kuratif dilakukan dengan eksekusi jaminan yang dimiliki oleh nasabah atau pengambilan AYDA (Aset yang diagunkan). Prosedurnya adalah divisi remedial akan memberikan surat penagihan saat jatuh tempo, jika masih nasabah masib belum melunasi kewajibannya maka akan memberikan surat peringatan kepada nasabah yang sudah ditandatangani oleh pejabat yang berwenang.

Jika surat peringatan I, II, dan III tidak diindahkan oleh nasabah, maka bank akan megeksekusi atau menguasai jaminan secara fisik. Jangka waktu antara surat peringatan I, II, dan III, serta III hingga eksekusi jaminan masing-masing adalah 14 hari. Selanjutnya nasabah akan membuat memo pelepasan jaminan untuk diserahkan kepada bank.

Penjualan jaminan selama ini yang dilakukan oleh BPRS Patriot Bekasi tidak dilakukan melalui pelelangan, akan tetapi bank akan mencarikan pihak pembeli yang sanggup untuk membeli barang jaminan tersebut. Selisih antara kewajiban nasabah dan harga jual barang jaminan akan dikembalikan oleh bank kepada nasabah.

4. Bantuan Manajemen 
Ariska, et al/Jurnal Ekonomi Syariah Teori dan Terapan Vol. 6 No. 12 Desember 2019: 2471-2484; PENYELESAIAN PEMBIAYAAN BERMASALAH AKAD MURABAHAH PADA BANK PEMBIAYAAN RAKYAT SYARIAH PATRIOT BEKASI

Tindakan bank memberikan bantuan teknis kepada nasabah dalam pengelolaan usahanya. Kriteria nasabah yang mendapat bantuan manajemen tersebut adalah:

a. nasabah perorangan dan/atau berbadan usaha

b. usaha nasabah yang masih prospektif.

c. bank mendapatkan personilnya untuk jangka waktu tertentu selama masih dianggap perlu.

d. harus ada kesepakatan bersama antara nasabah dan bank dalam bentuk MOU (Memorandum Of Understanding).

5. Penagihan oleh Pihak Ke-3

Prosedur penagihan oleh pihak ketiga ini dilakukan dengan menyerahkan berkas jaminan kepada kantor pengacara secara tertulis dan tanda terima. Berkas-berkas yang diperlukan yaitu akte pengikatan, surat jaminan, surat menyurat nasabah dengan bank dan profil nasabah. Untuk tahap pertama cukup diserahkan diserahkan fotokopi dari berkas-berkas tersebut. Pengacara diarahkan pada pola yang harus ditempuh dalam penyelesaian pembiayaan. Menurut Informan 3 penanganan oleh pihak ke tiga tidak pernah dilakukan oleh BPRS Patriot Bekasi.

6. Write Off (hapus buku) dan Write Off Final (hapus buku dan hapus tagih)

Penghapusan Piutang adalah suatu tindakan administratif bank untuk menghapus pembiayaan yang tidak dapat ditagih. Penyebabnya karena nasabah tidak mampu atau belum mampu melunasi, pembebasan hutang oleh bank, daluarsa dengan lewat waktu 30 tahun. Penghapusan piutang ini kondisi dimana nasabah bisa membayar tapi hanya semampunya saja, tergantung pada pendapatannya, sehingga besarnya tidak menentu. Tetapi jika memang nasabah benar-benar tidak bisa membayar atau nasabah menghilang tanpa jejak maka akan dihapus tagih (write of final) dengan membayarkan kewajiban nasabah dari dana zakat yang ada di BPRS. Seperti yang dijelaskan oleh informan 4 Bapak Asmawi sebagai Direksi BPRS Patriot Bekasi.

Pembiayaan yang dihapus harus tetap dijaga kerahasiaannya. Tegasnya, penghapusan tersebut tidak boleh diberitahukan kepada nasabah atau pihak lainnya. Tujuan penghapusan piutang ini dimaksudkan agar bank sebagai badan usaha cepat mengetahui posisi keuangan dan hasil usaha yang wajar dan realistis. Penghapusan atas suatu fasilitas pembiayaan hanya dapat dilakukan berdasarkan keputusan direksi baik denga dan atau tanpa usulan dari account officer dan atau divisi remidial.

Pertimbangan untuk menghapus suatu fasilitas pembiayaan adalah Kemungkinan hasil penagihan melalui proses hukum lebih kecil dibandingkan dengan biaya pengurusan, nasabah pembiayaan yang bersangkutan telah dinyatakan pailit oleh Pengadilan Negeri, 
Ariska, et al/Jurnal Ekonomi Syariah Teori dan Terapan Vol. 6 No. 12 Desember 2019: 2471-2484; PENYELESAIAN PEMBIAYAAN BERMASALAH AKAD MURABAHAH PADA BANK PEMBIAYAAN RAKYAT SYARIAH PATRIOT BEKASI

fasilitas pembiayaan yang telah lama diusahakan penagihannya, tetapi tidak menunjukkan hasil karena ketidakmampuan nasabah. Penghapusan piutang dilakukan setelah ada persetujuan dari panitia pembiayaan dan atau direksi. Usulan penghapusan piutang dibuat secara tertulis oleh pihak-pihak yang berwenang dalam bank.

\section{v. SIMPULAN}

\section{Kesimpulan}

Berdasarkan hasil penelitian dapat disimpulkan bahwa penyebab pembiayaan bermasalah diantaranya disebabkan oleh usaha nasabah menurun atau pendapatannya menurun, nasabah meninggal dunia dan nasabah berkarakter. Penyelesaian pembiayaan bermasalah dilakukan dengan menerapkan strategi-strategi pencegahan seperti melakukan analisis yang akurat, monitoring dan pengawasan yang intensif serta pelatihan manajerial. Jika telah dilakukan penerapan strategi tersebut masih terdapat pembiayaan bermasalah maka akan ditangani dengan beberapa cara, yaitu dengan tindakan prefentif (rescheduling), klaim pada asuransi, tindakan kuratif dengan mengeksekusi jaminan, bantuan manajemen, penagihan oleh pihak ketiga, tetapi cara ini belum pernah dilakukan oleh BPRS Patriot dan write off, serta write off final.

\section{Saran}

a. Bagi BPRS Patriot
BPRS Patriot harus menilai pengajuan pembiayaan dengan lebih akurat agar tidak terdapat nasabah yang bermasalah, serta melakukan monitoring dan pengawasan yang lebih intensif, sehingga mengurangi risiko kredit yang ditanggung oleh bank.

b. Bagi peneliti selanjutnya

Peneliti selanjutnya diharapkan bisa mendapat informasi mengenai penyelesaian pembiayaan bermasalah dari dua sisi, baik dari sisi bank maupun nasabah khususnya pada akad, sehingga hasil yang didapatkan semakin akurat.

\section{DAFTAR PUSTAKA}

\section{Sumber dari Literatur}

Adiwarman, Karim. 2011. Bank Islam Analisa Fiqih dan Keuangan. Jakarta: PT. Rajagrafindo Persada

Ahmad Rodoni dan Abdul Hamid. 2008. Lembaga Kevangan Syariah. Jakarta: Zikrul Hakim

Bungin,Burhan. 2007. Penelitian Kualitatif: Komunikasi, Ekonomi, Kebijakan Publik dan IImu Sosial lainnya. Jakarta:Putra Grafika

Etta Mamang Sangadji, Sopiah. 2010. Metodologi Penelitian. Yogyakarta

Djamil, Faturrahman. 2012. Penyelesaian Pembiayaan Barmasalah di Bank Syariah. Jakarta: Sinar Grafika

Ghoffar, M. Abdul, dkk. 2004. Tafsir Ibnu Katsir Jilid 1. Bogor: Pustaka Imam Asy-Syafi'i

Ismail. 2011. Perbankan Syariah Edisi 
Ariska, et al/Jurnal Ekonomi Syariah Teori dan Terapan Vol. 6 No. 12 Desember 2019: 2471-2484; PENYELESAIAN PEMBIAYAAN BERMASALAH AKAD MURABAHAH PADA BANK PEMBIAYAAN RAKYAT SYARIAH PATRIOT BEKASI

Pertama. Jakarta: Kencana

Koentjaraningrat. 1993. Metode-metode

Penelitian Masyarakat. Jakarta, Indonesia: PT. Gramedia.

Moch.Nazir. 2003. Metode Penelitian. Jakarta: Salemba Empat

Moleong, Lexy J. 2007 Metodologi Penelitian Kualitatif, Penerbit PT Remaja RosdakaryaOffset, Bandung

Muhammad.2005.

Manajemen Pembiayaan Bank Syariah. Yogyakarta: Unit Penerbit dan Percetakan (UPP) AMP YKPN

Statistik Otoritas Jasa Kuangan. 2019. Statistik Perbankan Syariah per Desember 2018

Siamat, Dahlan. 1993. Manajemen Lembaga Kevangan. Jakarta: Intermedia

Sukmadinata. 2006. Metode Penelitian Kualitatif. Bandung : Graha Aksara

Sugiyono. (2011). Metode Penelitian Kuantitatif, Kualitatif dan $R$ \& $D$. Bandung: Penerbit Alfabeta.

Yin, Robert K. 2008. Case Study Research: Design and Methods (Applied Social Research Methods). Illinois : Sage Publications, Inc

\section{Sumber dari Undang-Undang dan Fatwa}

FATWA DSN MUI No. 04/DSN-MUI/IV/2000

Tentang MURABAHAH

FATWA DSN-MUI No.47/DSN-MUI/II/2005

Tentang Penyelesaian Piutang

Murabahah Bagi Nasabah Tidak

Mampu Bayar

Undang-Undang nomor 10 tahun 1998 tentang perubahan atas UndangUndang nomor 7 tahun 1992 tentang perbankan (Lembaran Negara Republik Indonesia tahun 1998 nomor 182, Tambahan Lembaran Negara Republik Indonesia nomor 3790).

Undang-Undang nomor 21 tahun 2008 tentang perbankan syariah (Lembaran Negara Republik Indonesia tahun 2008 nomor 94, Tambahan Lembaran Negara Republik Indonesia nomor 4867)

Peraturan Bank Indonesia No. 06/17/PBI/2004 tentang Bank Pengreditan Rakyat berdasarkan prinsip syariah

Peraturan Pemerintah Nomor 72 tahun 1992 tentang Bank berdasarkan prinsip bagi hasil.

Peraturan Otoritas Jasa Keuangan Nomor 20/POJK.03/2014 tentang Bank Perkreditan Rakyat dikeluarkan dalam rangka mendorong pertumbuhan ekonomi nasional dan mendukung perkembangan usaha yang bersifat dinamis dengan perbankan nasional yang tangguh, termasuk industri Bank Perkreditan Rakyat yang sehat, kuat, produktif, dan memiliki daya saing agar mampu melayani masyarakat, terutama usaha mikro dan kecil.

Surat Keputusan Menteri Keuangan Republik Indonesia No. 792 Tahun 1990 tentang Lembaga Keuangan. 
Ariska, et al/Jurnal Ekonomi Syariah Teori dan Terapan Vol. 6 No. 12 Desember 2019: 2471-2484; PENYELESAIAN PEMBIAYAAN BERMASALAH AKAD MURABAHAH PADA BANK PEMBIAYAAN RAKYAT SYARIAH PATRIOT BEKASI 